\title{
Pengaruh Kepemimpinan, Kompensasi, Komunikasi, dan Motivasi Kerja terhadap Turnover Intention Pegawai dengan Kepuasan Kerja sebagai "Variabel Antara"
}

\author{
Siti Noor Hidayati \\ Universitas Proklamasi 45 Yogyakarta \\ Suryadi Dwi Saputra \\ Universitas Pembangunan Nasional Veteran Yogyakarta \\ Korespondensi penulis:datik_ng@yahoo.com
}

Article Info:

Received 30 June 2018

Accepted 2 July 2018

Available online 4 July 2018

Abstract: Leadership, compensation, communication, and work motivation positively affect the job satisfaction. Otherwise, job satisfaction negatively affect turnover intention. The results of 83 respondents of FTI UPN Veteran Yogyakarta employees can be explained as follows, it is proved significanly that there is an indirect influence of leadership, compensation, communication, and work motivation to turnover intention with job satisfaction as intermediate variable. While the direct effect of those variables are not significant. Between the four independent variables, the most dominant influence to increase job satisfaction and subsequently lower turnover intention is the work motivation.

Keywords: Compensation, Communication, Leadership, Work motivation, Turnover intention.

\section{PENDAHULUAN}

Sumber daya manusia (SDM) di dalam suatu organisasi/perusahaan merupakan suatu elemen yang esensial untuk menjalankan roda organisasi/perusahaan/lembaga guna mencapai tujuannya. Pada umumnya, kehidupan di dalam organisasi/perusahaan/ lembaga, apa pun bentuk dan sifatnya, baik yang bergerak di bidang perdagangan maupun jasa, akan selalu berusaha mencapai tujuan yang telah ditetapkan sebelumnya secara efektif dan efisien. Hal ini menuntut pihak manajemen untuk merencanakan, mengorganisasikan, menggerakkan, dan melakukan pengawasan terhadap sumber daya yang dimiliki. SDM merupakan sumber daya yang paling strategis dan penting di antara sumber daya lainnya. Melimpahnya sumber daya tanpa didukung sumber daya manusia yang berkualitas, akan mengganggu kelangsungan organisasi/perusahaan. Dengan demikian, organisasi memerlukan proses pengelolaan sumber daya manusia yang efektif 
di dalamnya. Namun, masalah yang seringkali dihadapi adalah adanya faktor sikap dan perilaku karyawan yang tidak dapat dikendalikan dalam proses pengelolaan sumber daya manusia. Tidak berhasilnya suatu organisasi dalam melakukan proses pengelolaan perilaku individu akan berujung pada kecendrungan turnover karyawannya. Hal ini bisa terjadi, jika organisasi yang menaunginya kurang memahami faktor yang mempengaruhi terbentuknya perilaku individu tersebut.

Turnover intention merupakan intensi karyawan untuk keluar dari pekerjaannya dan mengakibatkan perusahaan dihadapkan pada menurunnya kontinuitas karyawan dan tingginya biaya yang harus dikeluarkan untuk melakukan rekrutmen dan melatih karyawan baru. Apabila dalam diri karyawan memiliki keinginan untuk keluar menandakan keinginan yang tidak sejalan antara karyawan dan perusahaan. Semakin rendah tingkat kepuasan kerja karyawan akan memunculkan pemikiran untuk meninggalkan pekerjaannya (Waspodo dkk. 2013). Kepuasan kerja dipengaruhi antara lain oleh kepemimpinan (Bass et. al. 2003, dalam Suryadharma dkk. 2016), faktor finansial (kompenasi), faktor psikologis (motivasi kerja) dan (As'ad,2011) dan komunikasi (Gilmer dalam As'ad, 2011).

Uraian di atas menggambarkan bahwa kepemimpinan, kompensasi, komunikasi, dan motivasi kerja dapat mempengaruhi kepuasan kerja dan selanjutnya berpotensi mempengaruhi turnover intention. Dengan demikian, penelitian tentang variabelvariabel tersebut diperlukan untuk mengungkap pengaruhnya. Penelitian ini bertujuan untuk menganalisis pengaruh kepemimpinan, kompensasi, komunikasi, dan motivasi kerja tehadap turnover intention karyawan, baik secara langsung maupun tidak langsung dengan kepuasan kerja sebagai variabel antara, serta menentukan variabel mana yang pengaruhnya paling dominan. Penelitian ini diharapkan dapat memberikan informasi, masukan dan gambaran secara lebih jelas tentang pengaruh kepemimpinan, kompensasi, komunikasi, dan motivasi kerja terhadap kepuasan kerja dan turnover intention karyawan.

\section{KAJIAN TEORITIS}

Turnover intention merupakan perilaku karyawan yang memiliki hubungan erat dengan keinginan untuk keluar dari pekerjaannya. Harnoto (2012) menyatakan, "turnover intention adalah kadar atau intensitas keinginan untuk keluar dari perusahaan, banyak alasan yang menyebabkan timbulnya turnover intention ini, dan di antaranya adalah keinginan untuk mendapatkan pekerjaan yang lebih baik." Pendapat tersebut juga relatif sama dengan pendapat yang diungkapkan sebelumnya, bahwa intensi turnover pada dasarnya adalah keinginan untuk meninggalkan atau keluar dari perusahaan. Apabila di dalam diri karyawan memiliki keinginan untuk keluar menandakan keinginan yang tidak sejalan antara karyawan dan perusahaan. Turnover merupakan perilaku karyawan, yang memiliki hubungan erat dengan keinginan untuk keluar dari pekerjaannya mengakibatkan perusahaan dihadapkan pada penurunan kontinuitas karyawan dan tingginya biaya yang harus dikeluarkan untuk melakukan rekrutmen dan melatih karyawan baru.

Kepuasan kerja adalah seperangkat perasaan pegawai tentang menyenangkan atau tidaknya pekerjaan mereka (Umar, 2010). Kepuasan kerja mengacu pada sikap yang lazim ditunjukkan seseorang terhadap pekerjaannya. Seseorang dengan kepuasan kerja yang tinggi memiliki sikap positif terhadap pekerjaannya, begitu juga sebaliknya. Menurut Handoko (2014), kepuasan kerja adalah suatu perasaan positif tentang 
pekerjaan seseorang yang merupakan hasil dari karakteristiknya. Karyawan yang memiliki perasaan positif berarti ia merasa puas dengan pekerjaannya, sehingga akan lebih produktif daripada yang tidak puas. Kepuasan kerja merupakan tolok ukur yang sangat penting untuk mendapatkan perhatian di dalam praktik manajemen sumber daya manusia dan perilaku organisasi. Menurut Locke yang dikutip oleh Sopiah (2008), kepuasan kerja merupakan suatu ungkapan emosional yang bersifat positif atau menyenangkan sebagai hasil dari penilaian terhadap suatu pekerjaan atau pengalaman kerja. Menurut Siagian (2014), kepuasan kerja merupakan cara pandang seseorang, baik yang bersifat positif maupun negatif tentang pekerjannya. Menurut Robbins (2013), sikap umum terhadap pekerjaan seseorang yang mununjukkan perbedaan antara jumlah penghargaan yang diterima pekerja dan jumlah yang mereka yakini seharusnya mereka terima.

Kepemimpinan merupakan faktor yang dapat mempengaruhi kepuasan kerja (Bass et. al. 2003, dalam Suryadharma dkk. 2016). Menurut As'ad (2011) yang merangkum dari berbagai pendapat beberapa ahli seperti Harold E. Burt, Ghiselli dan Brown, Blum, Gilmer, Caugemi, dan Claypool, menyatakan bahwa ada empat faktor kepuasan kerja, yaitu faktor finansial, fisik, psikologi, dan sosial. Kompensasi merupakan bagian dari faktor finansial, sedangkan motivasi kerja merupakan bagian dari faktor psikologis yang menunjukkan minat individu terhadap pekerjaan. Komunikasi menurut Gilmer (dalam As'ad, 2011) merupakan salah satu faktor kepuasan kerja. Kepemimpinan sebagai proses mempengaruhi orang lain untuk mendapatkan pekerjaan yang secara efektif dan berperan untuk menimbulkan kepuasan kerja karyawan. Kepemimpinan adalah cara seorang pemimpin mempengaruhi perilaku bawahan agar mau bekerjasama dan bekerja secara produktif untuk mencapai tujuan organisasi (Hasibuan, 2012). Kepemimpinan diartikan pula sebagai pelaksanaan otoritas dan pembuatan keputusan (Dublin, dalam Thoha, 2012). Ada juga yang mengartikan suatu inisiatif untuk bertindak untuk menghasilkan suatu pola yang konsisten dalam rangka mencari jalan pemecahan dari suatu persoalan bersama (Hemphill dalam Thoha, 2012). Dengan kata lain, kepemimpinan adalah kemampuan mempengaruhi kelompok untuk mencapai tujuan kelompok tersebut. Peran kepemimpinan yang berjalan dengan baik dalam sebuah perusahaan/organisasi akan meningkatkan iklim kerja yang kondusif, sehingga dapat meningkatkan kepuasan kerja.

Kompensasi menjadi salah satu kebutuhan utama yang dibutuhkan oleh seorang karyawan selaku manusia untuk memenuhi kebutuhan hidupnya. Pemberian kompensasi harus dilakukan secara adil dan merata agar tercipta lingkungan kerja yang kondusif dan produktif bagi perusahaan. Kompensasi sangat penting bagi karyawan, karena besarnya kompensasi merupakan pencerminan atau ukuran nilai pekerjaan karyawan itu sendiri. Sebaliknya, besar kecilnya kompensasi dapat mempengaruhi prestasi kerja, motivasi, dan kepuasan kerja karyawan. Perusahaan harus dapat mengatur sedemikian rupa agar kompensasi yang diberikan kepada karyawan akan memperoleh kepuasan kerja dan termotivasi untuk berprestasi dan mencapai tujuan-tujuan perusahaan yang telah ditetapkan. Kompensasi dapat diartikan sebagai keseluruhan balas jasa yang diterima oleh karyawan karena telah melaksanakan pekerjaannya. Selanjutnya, perusahaan memberi kompensasi dalam bentuk uang, tunjangan, atau pun penghargaan yang bertujuan untuk memotivasi karyawan agar turut berpartisipasi dalam kegiatan pertumbuhan dan perkembangan perusahaan. Menurut Hasibuan (2012), kompensasi adalah semua pendapatan yang berbentuk uang, barang langsung, atau tidak langsung yang diterima karyawan sebagai imbalan atas jasa yang diberikan pada perusahaan. 
Menurut Umar (2010), kompensasi didefinisikan sebagai sesuatu yang diterima karyawan sebagai balas jasa tehadap mereka, yang didahuli oleh proses kompensasi. Proses kompensasi itu sendiri adalah suatu jaringan berbagai subproses untuk memberikan balas jasa kepada karyawan dalam pelaksanaan pekerjaan dan untuk memberikan kepuasan kerja mereka agar mencapai tingkat prestasi yang diinginkan. Menurut Ambar (2009), kompensasi adalah segala sesuatu yang diterima karyawan, sebagai balas jasa (kontra prestasi) atas kerja mereka. Menurut Handoko (2014), suatu cara yang dilakukan departemen personalia untuk meningkatkan prestasi kerja, motivasi, dan kepuasan kerja melalui kompensasi.

Komunikasi adalah proses penyampaian pikiran atau perasaan oleh seseorang kepada orang lain dengan menggunakan lambang-lambang yang bermakna bagi kedua pihak. Dalam situasi tertentu, komunikasi menggunakan media tertentu untuk mengubah sikap atau tingkah laku seseorang atau sejumlah orang, sehingga ada efek tertentu yang diharapkan. Dalam organisasi, komunikasi organisasi merupakan suatu hubungan timbal balik antarindividu dalam konteks organisasi. Komunikasi organisasi adalah pengiriman dan penerimaan berbagai pesan organisasi di dalam kelompok formal maupun informal di dalam suatu organisasi (Wiryanto, 2005).

Menurut Siagian (2014), motivasi kerja adalah daya dorong yang mengakibatkan seseorang atau organisasi mau dan rela untuk mengerahkan kemampuannya dalam bentuk keahlian atau ketrampilan, tenaga, dan waktu untuk menyelenggarakan berbagai kegiatan yang menjadi tanggung jawabnya dan menunaikan kewajibannya dalam rangka pencapaian tujuan dan berbagai sasaran organisasi yang telah ditentukan sebelumnya. Winardi (2004) mengatakan bahwa motivasi kerja adalah suatu kekuatan potensial yang ada di dalam diri seseorang manusia yang dapat dikembangkannya sendiri atau oleh sejumlah kekuatan luar yang pada intinya berkisar pada imbalan moneter dan nonmoneter dan dapat mempengaruhi hasil kinerjanya secara positif atau negatif. Motivasi kerja dipengaruhi oleh faktor internal, meliputi keinginan untuk dapat bertahan hidup, memiliki, memperoleh penghargaan, memperoleh pengakuan, dan berkuasa, dan faktor eksternal yang meliputi kondisi lingkungan kerja, kompensasi yang memadai, supervisi yang baik, adanya jaminan pekerjaan, penghargaan atas prestasi, peraturan yang fleksibel, serta status dan tanggung jawab (Sutrisno, 2011).

Robbins (2013) mendefinisikan motivasi sebagai proses yang menjelaskan intensitas, arah, dan ketekunan seorang individu untuk mencapai suatu tujuan, sedangkan Hasibuan (2012) memberikan pengertian motivasi secara sederhana sebagai pemberian daya penggerak yang menciptakan gairah kerja seseorang agar mereka mau bekerja sama, bekerja efektif, dan terintegrasi dengan segala upayanya untuk mencapai kepuasan. Berdasarkan beberapa pengertian motivasi di atas, maka dapat disimpulkan bahwa motivasi timbul dari diri sendiri untuk pemenuhan kebutuhan individualnya dan juga bisa dikarenakan dorongan orang lain. Namun, motivasi yang paling baik adalah dari diri sendiri karena dilakukan tanpa paksaan dan setiap individu memiliki motivasi yang berbeda untuk mencapai tujuannya. Pemberian motivasi yang dilakukan oleh suatu perusahaan baik publik maupun bisnis harus dapat memenuhi beberapa tujuan. Ada banyak tujuan pemberian motivasi, salah satu di antaranya adalah untuk meningkatkan kepuasan kerja karyawan (Hasibuan, 2012).

Dari uraian tersebut, peningkatan peran kepemimpinan, kompensasi, komunikasi, dan motivasi kerja akan meningkatkan kepuasan kerja, sehingga pada gilirannya akan menurunkan turnover intention. Penelitian ini diharapkan dapat memberikan informasi, 
masukan dan gambaran pada FTI UPN Veteran Yogyakarta tentang pengaruh kepemimpinan, kompensasi, komunikasi, dan motivasi kerja terhadap kepuasan kerja dan turnover intention karyawan. Turnover intention karyawan menjadi faktor penting penting dalam pengambilan keputusan manajemen sumber daya manusia. Dengan demikian, permasalahan dalam penelitian ini adalah Apakah kepemimpinan, kompensasi, komunikasi, dan motivasi kerja berpengaruh langsung atau tidak langsung terhadap turnover intention dengan kepuasan kerja sebagai variabel antara?

Berdasar uraian di depan dapat dijelaskan kerangka pikir dalam penelitan ini sebagai berikut: Turnover Intention merupakan perilaku karyawan yang memiliki hubungan erat dengan keinginan untuk keluar dari pekerjaannya. Harnoto (2012) menyatakan, "turnover intention adalah kadar atau intensitas dari keinginan untuk keluar dari perusahaan. Kurangnya kepuasan kerja merupakan salah satu faktor yang dapat menimbulkan keinginan seseorang untuk meninggalkan pekerjaan mereka. Menurut Handoko (2014) kepuasan kerja adalah suatu perasaan positip tentang pekerjaan seseorang yang merupakan hasil dari karakteristiknya. Karyawan yang memiliki perasaan positip, artinya telah puas dengan pekerjaannya, sehingga akan lebih produktif dari pada yang tidak puas. Kepuasan kerja merupakan suatu hal yang sangat penting untuk mendapatkan perhatian di dalam praktek manajemen sumber daya manusia dan perilaku organisasi.

Banyak faktor yang mempengaruhi kepuasan kerja diantaranya adalah faktor kepemimpinan (I.M.A. Suryadharma dkk, 2016), faktor kompensasi, faktor motivasi kerja dan faktor komunikasi (As'ad, 2011). Kepemimpinan adalah cara seorang pemimpin mempengaruhi perilaku bawahan agar mau bekerjasama dan bekerja secara produktif untuk mencapai tujuan organisasi (Hasibuan MSP, 2012). Kompensasi adalah semua pendapatan yang berbentuk uang, barang langsung atau tidak langsung yang diterima karyawan sebagai imbalan atas jasa yang diberikan pada perusahaan (Hasibuan, 2012). Komunikasi adalah proses penyampaian pikiran atau perasaan oleh seseorang kepada orang lain dengan menggunakan lambang-lambang yang bermakna bagi kedua pihak, dalam situasi yang tertentu komunikasi menggunakan media tertentu untuk mengubah sikap atau tingkah-laku seseorang atau sejumlah orang sehingga ada efek tertentu yang diharapkan (Wiryanto, 2005). Pengertian motivasi secara sederhana adalah pemberian daya penggerak yang menciptakan gairah kerja seseorang, agar mereka mau bekerja sama, bekerja efektif dan terintegrasi dengan segala upayanya untuk mencapai kepuasan (Hasibuan, 2012). Kerangka pikir penelitian ini digambarkan pada Gambar 1.

Berkenaan dengan kerangka pikir tersebut (Gambar 1), maka hipotesis yang dikemukakan dalam penelitian ini adalah:

1. Ada pengaruh kepemimpinan, kompensasi, komunikasi, dan motivasi kerja tehadap kepuasan kerja karyawan FTI UPN Veteran Yogyakarta, baik secara bersama-sama maupun secara parsial.

2. Ada pengaruh kepemimpinan, kompensasi, komunikasi, motivasi kerja, dan kepuasan kerja terhadap turnover intention karyawan FTI UPN Veteran Yogyakarta, baik secara bersama-sama maupun secara parsial. 


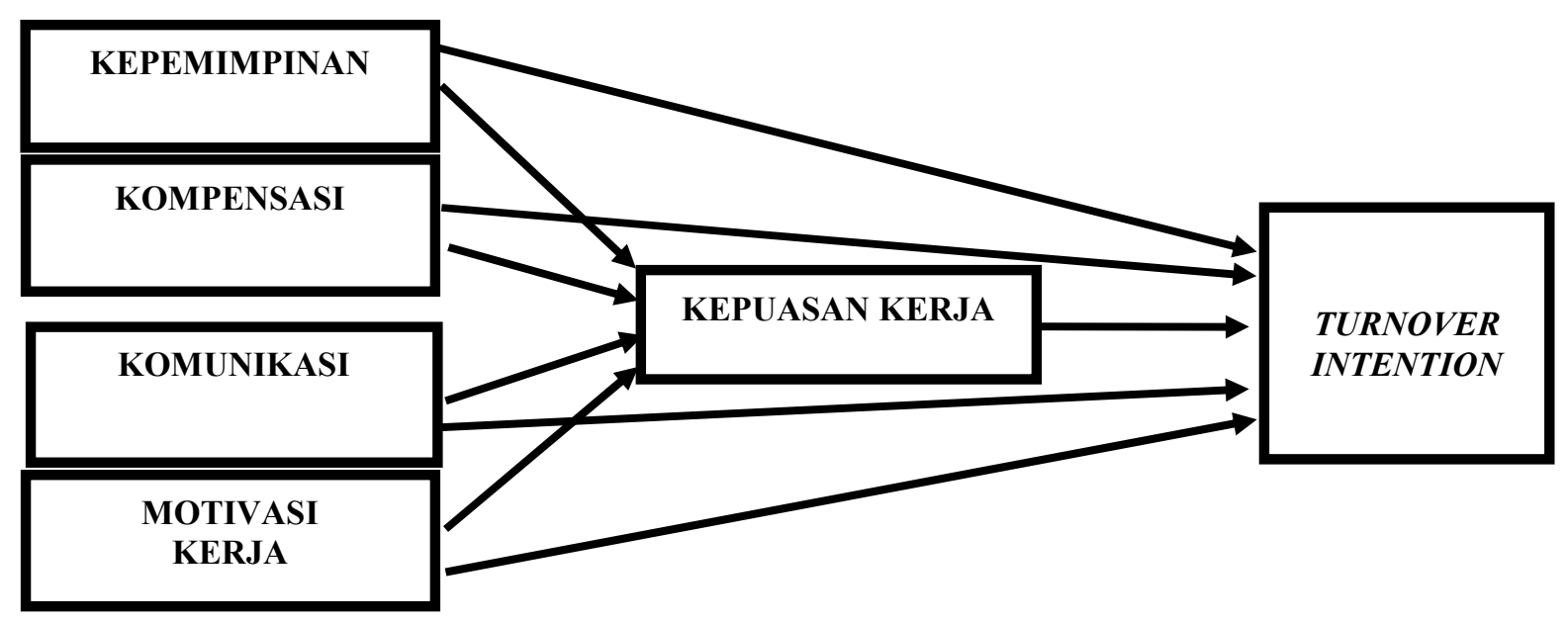

Gambar 1. Kerangka Pikir Penelitian

\section{METODE PENELITIAN}

Penelitian ini dilakukan terhadap karyawan di lingkungan Fakultas Teknik Industri (FTI) Universitas Pembangunan Nasional Veteran Yogyakarta (UPNV). Populasi dalam penelitian ini adalah semua karyawan FTI UPNV yang berjumlah 83 orang. Semua populasi dijadikan responden, sehingga penelitian ini menggunakan metode sensus (Sugiyono, 2013). Variabel-variabel yang diteliti dalam penelitian ini meliputi:

\section{Untuk hipotesis 1:}

Variabel bebas (independent variable) adalah kepemimpinan (X1), kompensasi (X2), komunikasi (X3), dan motivasi kerja (X4), sedangkan variabel tergantung (dependent variable) adalah kepuasan kerja karyawan (Y).

\section{Untuk hipotesis 2:}

Variabel bebas (independent variable) adalah kepemimpinan (X1), kompensasi (X2), komunikasi (X3), motivasi kerja (X4), dan kepuasan kerja karyawan (Y), sedangkan variabel tergantung (dependent variable) adalah turnover intention (Z).

Data yang digunakan dalam penelitian ini adalah data primer dari responden dan data sekunder dari berbagai referensi terkait. Metode pengumpulan data primer yang digunakan adalah penggunaan kuesioner atau angket, sedangkan metode pengukurannya menggunakan skala Likert, yaitu skala yang digunakan untuk mengukur sikap, pendapat, dan persepsi dari responden tentang fenomena sosial (Sugiyono, 2013). Jawaban dari setiap butir pernyataan disediakan lima alternatif jawaban dan penilaian untuk masing-masing alternatif jawaban diberikan bobot (skor): (a) Sangat Tidak Setuju (STS) dengan skor 1; (b) Tidak Setuju (TS) dengan skor 2; (c) Netral (N) dengan skor 3; (d) Setuju (S) dengan skor 4; dan (e) Sangat Setuju (SS) dengan skor 5.

Angket berisi pernyataan sesuai dengan indikator masing-masing variabel, yaitu: variabel kepemimpinan (X1) terdiri atas 8 butir pernyataan; variabel kompensasi (X2) 9 
butir pernyataan, variabel komunikasi (X3) 9 butir pernyataan, variabel motivasi kerja (X4) 5 butir pernyataan, variabel kepuasan kerja karyawan (Y) 8 butir pernyataan, dan variabel turnover intention (Z) 8 butir pernyataan. Uji validitas dan uji reliabilitas terhadap semua butir angket dari enam variabel tersebut telah dilakukan dengan sampel 30 orang karyawan. Uji validitas dilakukan dengan menghitung korelasi Pearson Product Moment (ryx). Hasil perhitungan semua butir pernyataan pada masing-masing variabel diperoleh nilai ryx-hitung lebih besar dibandingkan r-hitung $(0,361)$, sehingga semua butir pernyataan tersebut dinyatakan valid. Uji reliabilitas menggunakan perhitungan Cronbach Alpha, hasilnya menunjukkan bahwa nilai alpha keenam variabel tersebut semuanya di atas 0,7 sehingga semua variabel dinyatakan reliabel.

Metode analisis data yang digunakan dalam penelitian ini adalah analisis kualitatif dan kuantitatif sebagai berikut:

1. Untuk menganalisis karakteristik responden (karyawan) digunakan analisis kualitatif, yaitu analisis dengan menggunakan paparan sederhana, baik jumlah data maupun persentase dengan membuat distribusi frekuensi (Arikunto, 2013).

2. Untuk menganalisis tanggapan responden (karyawan) terhadap keenam variabel digunakan distribusi frekuensi dan nilai rata-rata hitung (mean) dengan interval [(5$1) / 5=0,8]$. Ada lima kriteria yang digunakan, yaitu sangat rendah $(1,00-1,80)$, rendah $(1,81-2,60)$, cukup $(2,61-3,40)$, tinggi $(3,41-4,20)$, dan sangat tinggi $(4,21-$ $5,00)$.

3. Untuk menganalisis pengaruh variabel $\mathrm{X} 1-\mathrm{X} 4$ terhadap $\mathrm{Z}$ secara tidak langsung dengan variabel antara $Y$ maupun pengaruhnya secara langsung dengan menggunakan analisis regresi berganda dan analisis jalur (Ghozali, 2008). Uji asumsi dasar normalitas, lineatitas, dan homogenitas, serta uji asumsi klasik, yaitu multikolinearitas dan heteroskedastisitas telah dilakukan, dan hasilnya menunjukkan bahwa model penelitian ini sudah memenuhi syarat untuk dilakukan analisis lebih lanjut. Uji asumsi klasik autokorelasi tidak dilakukan karena data yang digunakan berupa cross-section.

4. Untuk mengetahui variabel independen (Xn) mana yang paling dominan pengaruhnya terhadap variabel dependen kinerja pegawai $(Z)$ dapat dilihat dari standardized total effect terbesar.

Model persamaan regresi berganda sebagai berikut:

$Y=\beta_{1} X_{1}+\beta_{2} X_{2}+\beta_{3} X_{3}+\beta_{4} X_{4}+\varepsilon 1$

$Z=\beta_{1} X_{1}+\beta_{2} X_{2}+\beta_{3} X_{3}+\beta_{4} X_{4}+\beta_{4} X+\beta_{5} Y+\varepsilon 2$

Model struktural analisis jalur penelitian ini digambarkan pada Gambar 2 berikut ini: 


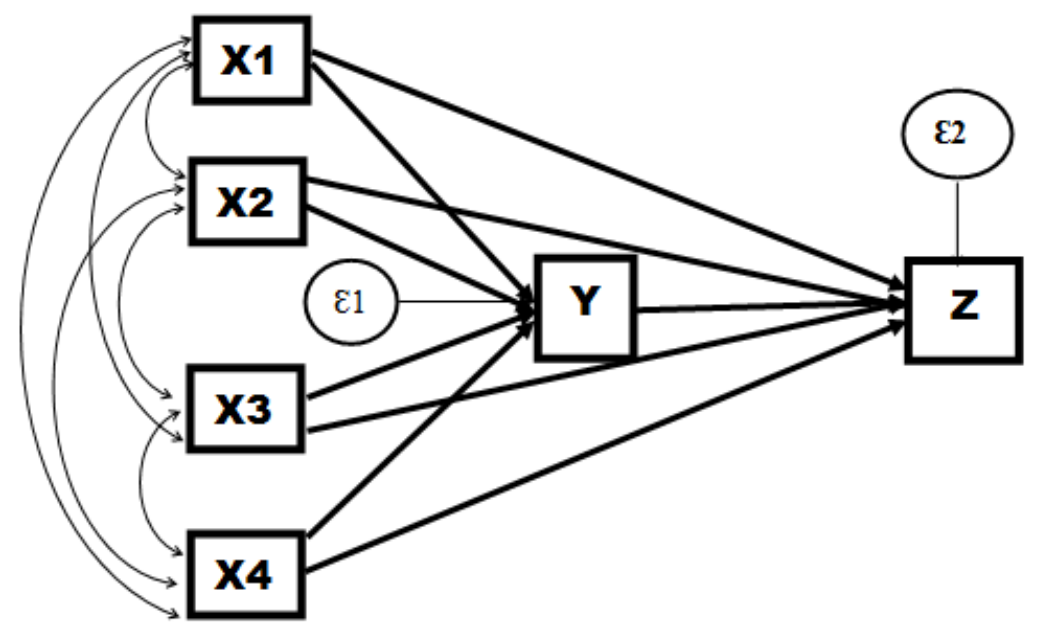

Gambar 2. Model Struktural Analisis Jalur

\section{HASIL PENELITIAN DAN PEMBAHASAN}

Pengumpulan data dengan angket dilakukan terhadap 83 responden atau semua karyawan di FTI UPN. Setelah dilakukan analisis diperoleh hasil sebagai berikut:

1. Responden terbanyak adalah laki-laki sebanyak 59 orang $(71,1 \%)$, usia berkisar antara 40-49 tahun yaitu 46 orang $(55,4 \%)$, pendidikan SMA/SMK sebanyak 38 orang $(45,8 \%)$, dan masa kerja berkisar antara 11-20 tahun yaitu 46 orang $(55,4 \%)$.

2. Tanggapan responden (karyawan) terhadap implementasi masing-masing variabel kepemimpinan (X1), kompensasi (X2), komunikasi (X3), motivasi kerja (X4), kepuasan kerja karyawan (Y), dan turnover intention (Z) sebagai berikut:

a. Kepemimpinan (X1), dari 8 butir pernyataan, sebagian besar pegawai $(60,2 \%)$ menyatakan setuju bahwa organisasi/kantor telah memperhatikan faktor kepemimpinan dengan nilai rata-rata skor (mean) sebesar 3,79 (tinggi), berarti implementasi kepemimpinan baik.

b. Kompensasi (X2), dari 9 butir pernyataan, sebagian besar pegawai $(56,6 \%)$ menyatakan setuju bahwa organisasi/kantor telah memperhatikan faktor kompensasi dengan nilai rata-rata skor (mean) sebesar 3,74 (tinggi), berarti implementasi kompensasi baik.

c. Komunikasi (X3), dari 9 butir pernyataan tersebut, sebagian besar pegawai $(62,7 \%)$ menyatakan setuju bahwa organisasi/kantor telah memperhatikan faktor komunikasi dengan nilai rata-rata skor (mean) sebesar 3,82 (tinggi), berarti implementasi komunikasi baik.

d. Motivasi kerja (X4), dari 5 butir pernyataan tersebut, sebanyak 49,4\% pegawai menyatakan setuju bahwa organisasi/kantor telah memperhatikan faktor motivasi kerja dengan nilai rata-rata skor (mean) sebesar 3,66 (tinggi), berarti implementasi motivasi kerja baik.

e. Kepuasan kerja karyawan (Y), dari 8 butir pernyataan, sebagian besar pegawai $(61,4 \%)$ menyatakan setuju bahwa karyawan/pegawai mempunyai kepuasan kerja terhadap organisasi/kantor dengan nilai rata-rata skor (mean) sebesar 3,9 (tinggi), berarti kepuasan kerja karyawan baik. 
f. Turnover intention $(\mathrm{Z})$, dari 8 butir pernyataan tersebut, sebagian besar pegawai $(65,1 \%)$ menyatakan tidak setuju bahwa pegawai kantor melakukan turnover intention dengan nilai rata-rata skor (mean) sebesar 2,6 (rendah), berarti keinginan karyawan/pegawai keluar dari pekerjaannya rendah.

3. Berdasar hasil analisis dengan program SPSS diperoleh hasil sebagai berikut:

Tabel 1. Standardized Regression Weights

\begin{tabular}{|c|c|c|c|c|}
\hline Regression weights & Estimate & SE & CR & $\mathbf{P}$ \\
\hline 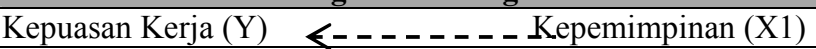 & 0,284 & 0,083 & 3,418 & 0,001 \\
\hline Ł_...... Kompensasi (X2) & 0,296 & 0,076 & 3.892 & 0,000 \\
\hline 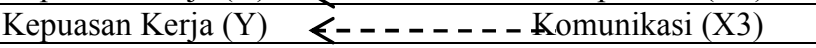 & 0,234 & 0,082 & 2.854 & 0,006 \\
\hline ८------- - Motivasi Kerja (X4) & 0,287 & 0,077 & 3,722 & 0,000 \\
\hline \multicolumn{5}{|l|}{$\varepsilon 1=0,2265$} \\
\hline く- - - - Kepemimpinan (X1) & $-0,059$ & 0,058 & $-1,011$ & 0,315 \\
\hline Turnover Intention $(\mathrm{Z}) \quad \measuredangle-------$ Kompensasi (X2) & $-0,085$ & 0,054 & -1.562 & 0,122 \\
\hline <__. _ _ Komunikasi (X3) & $-0,057$ & 0,056 & -1.008 & 0,317 \\
\hline Turnover Intention (Z) Ł-_. _ _ _ Motivasi Kerja (X4) & $-0,086$ & 0,055 & -1.570 & 0,120 \\
\hline Turnover Intention $(\mathrm{Z}) \quad \measuredangle-\ldots \ldots \ldots \ldots$ Kepuasan $\operatorname{Kerja}(\mathrm{Y})$ & $-0,580$ & 0,074 & -7.813 & 0,000 \\
\hline
\end{tabular}

Sumber: Hasil pengolahan data, 2018.

Tabel 2. ANOVA

\begin{tabular}{cccc}
\hline Model & Df & F & Sig. \\
\hline $\mathrm{Y}=\mathrm{f}(\mathrm{X} 1, \mathrm{X} 2, \mathrm{X} 3, \mathrm{X} 4)$ & $\mathrm{df}-1=4, \mathrm{df}-2=78$, total $=82$ & 19,165 & .000 \\
\hline $\mathrm{Z}=\mathrm{f}(\mathrm{X} 1, \mathrm{X} 2, \mathrm{X} 3, \mathrm{X} 4, \mathrm{Y})$ & $\mathrm{df}-1=5, \mathrm{df}-2=77$, total $=82$ & 37,623 & .000 \\
\hline
\end{tabular}

Sumber: Hasil pengolahan data, 2018.

Persamaan Regresi dengan standardized coefficients:

$$
\begin{aligned}
& Y=0,284 X_{1}+0,296 X_{2}+0,234 X_{3}+0,287 X_{4}+0,227 \\
& Z=-0,059 X_{1}-0,085 X_{2}-0,057 X_{3}-0,086 X_{4}-0,580 Y+0,149
\end{aligned}
$$

Hasil analisis model struktural analisis jalur digambarkan pada Gambar 3 berikut ini:

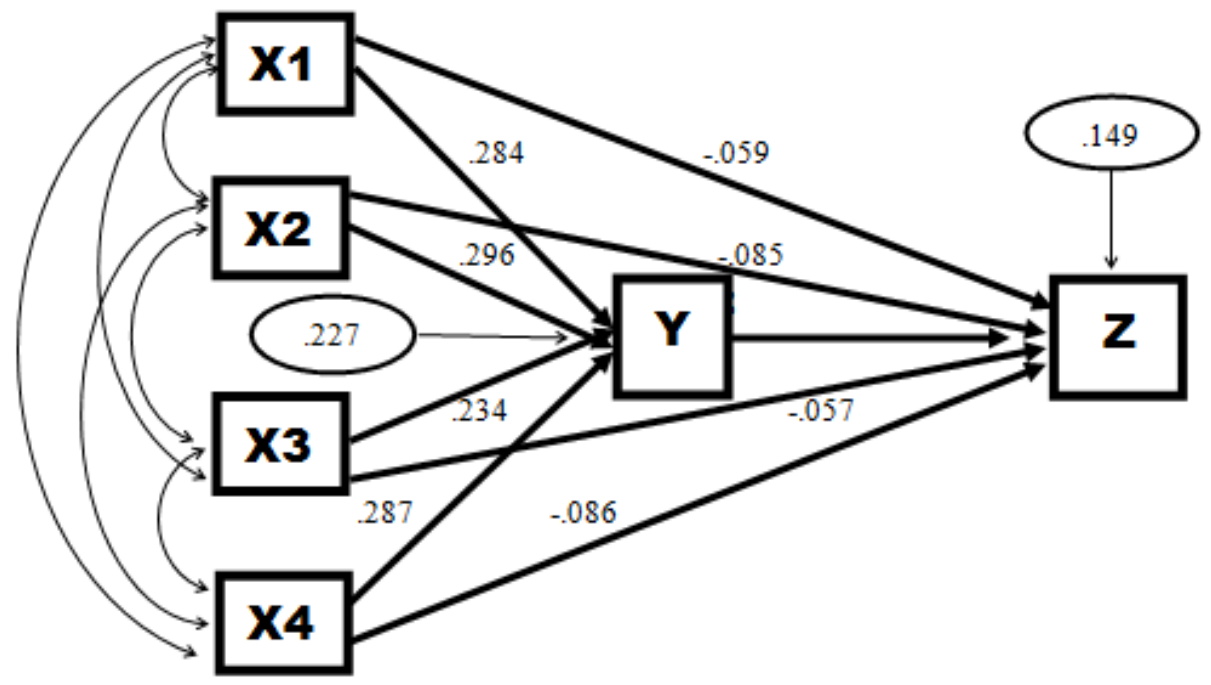

Gambar 3. Hasil Analisis Model Struktural Analisis Jalur 
Dari Tabel 1 dan Tabel 2, terbukti ada pengaruh positif dan signifikan secara parsial dari kepemimpinan (X1), kompensasi (X2), komunikasi (X3), dan motivasi kerja (X4) terhadap kepuasan kerja karyawan (Y). Di sisi lain, ada pengaruh negatif dan signifikan dari kepuasan kerja karyawan (Y) terhadap turnover intention (Z). Nilai probabilitas semuanya berada di bawah nilai 0,05 , sedangkan pengaruhnya secara bersama-sama adalah signifikan yang ditunjukkan dengan nilai F-hitung 19,165 dengan tingkat signifikansi 0.000. Untuk pengaruh langsung secara parsial dari kepemimpinan (X1), kompensasi (X2), komunikasi (X3), dan motivasi kerja (X4) secara parsial terhadap turnover intention $(\mathrm{Z})$, pengaruhnya ada tetapi sangat kecil, sehingga secara statistik dikatakan tidak signifikan dengan nilai probabilitas semuanya di atas nilai 0,05 , sedangkan pengaruh kepuasan kerja karyawan (Y) terhadap turnover intention $(\mathrm{Z})$ adalah negatif dan signifikan dengan nilai probabilitas 0,000 . Untuk pengaruh secara bersama adalah signifikan yang ditunjukkan dengan nilai F-hitung=37,623 dengan tingkat signifikansi 0,000. Hasil tersebut menggambarkan bahwa pengaruh dari kepemimpinan (X1), kompensasi (X2), komunikasi (X3), dan motivasi kerja (X4) terhadap turnover intention (Z) terbukti pengaruhnya secara tidak langsung melalui variabel kepuasan kerja karyawan (Y) sebagai variabel antara, sedangkan pengaruhnya secara langsung terbukti tidak signifikan. Pengaruh positif menggambarkan bahwa meningkatnya kepemimpinan (X1), kompensasi (X2), komunikasi (X3), dan motivasi kerja (X4) akan meningkatkan kepuasan kerja karyawan (Y), sedangkan pengaruh negatif menggambarkan meningkatnya kepuasan kerja karyawan (Y) akan menurunkan turnover intention $(\mathrm{Z})$.

Tabel 3. Standardized Direct Effect

\begin{tabular}{crrrrr}
\hline Variabel & Kepemimpinan & Kompensasi & \multicolumn{1}{c}{ Komunikasi } & $\begin{array}{c}\text { Motivasi } \\
\text { Kerja }\end{array}$ & $\begin{array}{c}\text { Kepuasan } \\
\text { Kerja }\end{array}$ \\
\hline $\begin{array}{c}\text { Kepuasan } \\
\text { Kerja }\end{array}$ & 0,287 & 0,323 & 0,235 & 0,312 & 0,000 \\
\hline $\begin{array}{c}\text { Turnover } \\
\text { Intention }\end{array}$ & $-0,070$ & $-0,108$ & $-0,067$ & $-0,109$ & $-0,676$ \\
\hline
\end{tabular}

Sumber: Hasil pengolahan data, 2018.

Tabel 4. Standardized Indirect Effect

\begin{tabular}{crrrrr}
\hline Variabel & Kepemimpinan & \multicolumn{1}{c}{ Kompensasi } & Komunikasi & $\begin{array}{c}\text { Motivasi } \\
\text { Kerja }\end{array}$ & $\begin{array}{c}\text { Kepuasan } \\
\text { Kerja }\end{array}$ \\
\hline $\begin{array}{c}\text { Kepuasan } \\
\text { Kerja }\end{array}$ & 0,000 & 0,000 & 0,000 & 0,000 & 0,000 \\
\hline $\begin{array}{c}\text { Turnover } \\
\text { Intention }\end{array}$ & $-0,194$ & $-0,218$ & $-0,159$ & $-0,211$ & 0,000 \\
\hline
\end{tabular}

Sumber: Hasil pengolahan data, 2018.

Tabel 5. Standardized Total Effect

\begin{tabular}{crrrrr}
\hline Variabel & Kepemimpinan & Kompensasi & Komunikasi & $\begin{array}{c}\text { Motivasi } \\
\text { Kerja }\end{array}$ & $\begin{array}{c}\text { Kepuasan } \\
\text { Kerja }\end{array}$ \\
\hline $\begin{array}{c}\text { Kepuasan } \\
\text { Kerja }\end{array}$ & 0,283 & 0,232 & 0,233 & 0,315 & 0,000 \\
\hline $\begin{array}{c}\text { Turnover } \\
\text { Intention }\end{array}$ & $-0,264$ & $-0,326$ & $-0,226$ & $-0,401$ & $-0,676$ \\
\hline
\end{tabular}

Sumber: Hasil pengolahan data, 2018. 
4. Tabel 3 menggambarkan standardized koefisien $\beta$ untuk pengaruh kepemimpinan (X1), kompensasi (X2), komunikasi (X3), dan motivasi kerja (X4) terhadap kepuasan kerja karyawan (Y), dan standardized koefisien $\beta$ untuk pengaruh langsung (direct effect) kepemimpinan (X1), kompensasi (X2), komunikasi (X3), motivasi kerja (X4), kepuasan kerja karyawan (Y) terhadap turnover intention (Z).

Tabel 4 menggambarkan standardized pengaruh tidak langsung (indirect effect) yang dapat dihitung dari Tabel 2, sebagai berikut: Untuk pengaruh X1 terhadap Y selanjutnya $\mathrm{Y}$ terhadap $Z=0,287 \mathrm{x}-0,676=-0,194$. Untuk pengaruh $\mathrm{X} 2$ terhadap $\mathrm{Y}$ selanjutnya $\mathrm{Y}$ terhadap $Z=0,323 \mathrm{x}-0,676=-0,218$. Untuk pengaruh $\mathrm{X} 3$ terhadap $\mathrm{Y}$ selanjutnya $\mathrm{Y}$ terhadap $Z=0,235 \mathrm{x}-0,676=-0,159$. Untuk pengaruh $\mathrm{X} 4$ terhadap Y selanjutnya $Y$ terhadap $Z$ ) $=0,312 x-0,676=-0,211$.

Tabel 5 adalah standardized pengaruh total (total effect) yang merupakan penjumlahan dari direct effect (Tabel 3) + indirect effect (Tabel 4). Penjumlahan dari angka-angka di Tabel 3 dan Tabel 4 sesuai dengan variabel masing-masing, yaitu: Untuk $X 1$ terhadap $Z=-0,07-0,194=-0,264$. Untuk $X 2$ terhadap $Z=-0,108$ $0,218=-0,326$. Untuk $X 3$ terhadap $Z=-0,067-0,159=-0,226$. Untuk X4 terhadap $\mathrm{Z}=-0,109-0,211=-0,32$.

Dari Tabel 5 standardized total effect bisa diketahui bahwa nilai terbesar adalah 0,326 yaitu variabel kompensasi (X2) yang menggambarkan bahwa pengaruhnya terhadap meningkatnya kepuasan kerja (Y) selanjutnya terhadap penurunan turnover intention $(\mathrm{Z})$ adalah paling besar (dominan), kemudian diikuti variabel motivasi kerja (X4) sebesar 0,320, kepemimpinan (X1) sebesar 0,264, dan komunikasi (X3) sebesar 0,226.

\section{KESIMPULAN DAN SARAN}

Dari hasil penelitian dan pembahasan di atas dapat disimpulkan bahwa:

1. Sebagian besar responden adalah laki-laki $(71,1 \%)$, usianya berkisar antara 40-49 $(55,4 \%)$, berpendidikan SMA/SMK $(45,8 \%)$, dan masa kerja berkisar antara 11-20 tahun $(55,4 \%)$.

2. Tanggapan responden (karyawan) terhadap implementasi masing-masing variabel kepemimpinan, kompensasi, komunikasi, dan motivasi kerja, kepuasan kerja karyawan adalah baik dengan skor rata-rata berada pada interval 3,41-4,2, sedangkan intensi karyawan untuk keluar (turnover intention) adalah rendah dengan skor rata-rata 2,6.

3. Pengaruh variabel kepemimpinan (X1), kompensasi (X2), komunikasi (X3), dan motivasi kerja (X4) terhadap turnover intention (Z) terbukti pengaruhnya secara tidak langsung melalui variabel kepuasan kerja karyawan (Y) sebagai variabel antara, sedangkan pengaruhnya secara langsung terbukti tidak signifikan.

4. Pengaruh yang paling dominan untuk menaikkan kepuasan kerja karyawan (Y) yang selanjutnya menurunkan turnover intention $(\mathrm{Z})$ adalah variabel kompensasi (X2).

Saran yang diajukan untuk pengembangan lebih lanjut adalah melakukan penelitian berikutnya dengan mengembangkan variabel-variabel yang diteliti. Berdasarkan teori-teori yang ada, banyak variabel-variabel yang mempengaruhi kinerja pegawai. Penelitian ini baru mengkaji empat variabel dengan nilai koefisien determinasi $\left(\mathrm{R}^{2}\right)$ sebesar $50 \%$. Dengan demikian, penelitian ini diharapkan mampu berkontribusi 
dalam memberikan pertimbangan kebijakan-kebijakan yang diambil perusahaan untuk meningkatkan kinerja pewgawai.

\section{DAFTAR REFERENSI}

Arikunto, S. (2013). Prosedur Penelitian Suatu Pendekatan Praktik. Jakarta: PT Rineka Cipta.

As'ad, M. (2011). Seri Ilmu Sumber Daya Manusia: Psikologi Industri. Yogyakarta: Liberty.

Ghozali, I. (2008). Model Persamaan Struktural, Konsep dan Aplikasi Dengan Program AMOS. Semarang: Badan Penerbit Universitas Diponegoro.

Handoko, T. H. (2014). Manajemen Personalia dan Sumberdaya Manusia. Yogyakarta: BPFE UGM.

Harnoto (2012). Manajemen Sumber Daya Manusia. Jakarta: PT. Prehallindo.

Robbins, P. S. (2013). Perilaku Oirganisasi. Jakarta: Indeks Gramedia Group.

Siagian, S. P. (2014). Manajemen Sumber Daya Manusia. Jakarta: Bumi Aksara.

Sopiah (2014). Perilaku Organisasi. Yogyakarta: Penerbit Andi.

Sugiyono (2013). Metode Penelitian Bisnis. Bandung: Penerbit Alfabeta.

Sulistiyani, A. T. \& Rosidah (2009). Manajemen Sumber Daya Manusia. Yogyakarta: Graha Ilmu.

Suryadharma, I.M.A., Riana, I.G., \& Sintaasih, D.K. (2016). Pengaruh Kepemimpinan dan Kompensasi terhadap Kepuasan Kerja dan Kinerja Karyawan. E-Journal Ekonomi dan Bisnis, Universitas Udayana 5 (2) 335-358.

Sutrisno, E. (2011). Manajemen Sumber Daya Manusia. Jakarta: Penerbit Kencana.

Thoha, M. (2012). Perilaku Organisasi Konsep Dasar dan Implikasinya. Jakarta: PT Raja Grafindo Persada.

Umar, H. (2010). Design Penelitian MSDM dan Perilaku Karyawan: Paradigma Positivistik dan Berbasis Pemecahan Masalah. Jakarta: Rajawali Pers.

Waspodo, A.A.W.S., Handayani, N.C., \& Paramita, W. (2013). Pengaruh Kepuasan Kerja dan Stres Kerja terhadap Turnover Intention pada Karyawan PT. Unitex di Bogor. Jurnal Riset Manajemen Sains Indonesia (JRSMI) 4 (1) 97-115.

Winardi (2004). Manajemen Perilaku Organisasi. Jakarta: Prenada Media.

Wiryanto (2005). Pengantar Ilmu Komunikasi. Jakarta: PT Grasindo Widjaja. 